\title{
ABNORMAL BÉKÉSY TRACINGS IN EARS WITH SENSORINEURAL DEAFNESS
}

By

TokURo SUZUKI, M.D.

From the Department of Otolaryngology, Faculty of Medicine, Shinshu University, Matsumoto

Amplitude of fixed-frequency Békésy tracing in normal and abnormal ears was discussed. The paper covers following items: (1) components of amplitude of Békésy tracing, (2) normal amplitude for continuous and interrupted tones, (3) abnormal narrow amplitude in the ears with sensorineural deafness, (4) relation between narrow amplitude and recruitment phenomenon, (5) narrow amplitude and frequency of test tones, (6) narrow amplitude for continuous and interrupted test tones, (7) decrease in amplitude in normal ears after exposure to loud tones, ( 8 ) relation between narrow amplitude and abnormal auditory adaptation.

\section{感音性難聴が Békésy オージオグラム上に 示す異常現象に関連して}

信州大学医学部耳鼻咽诶科学教室教授

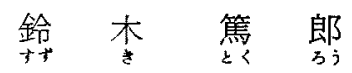

目次

1. 緒 言

2. 振幅の橉成

3. 正常振幅

4. 持続音振幅上断続㫮振幅

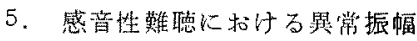

6. 振雷樎小上 recruitment

7. 振幅変調脈音比上る振幅縮小の消脣

8. 正常耳音绠負荷後の振幅縮小

9. 結 語

\section{1. 緒 言}

1947 年 Békésy 2)によつて発表された連続周波数自 記オージオメータ(Békésy オージオメータ) 估，その 後一般閥值測定の目的火便用されるよりは，難聴の鑑別 榕断のための一つの新しい乎段として唡討され，その見 地から多くの研究がなされてきた。加が国に批いても立

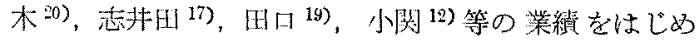
いくつかの研究が発表されている.

現在，鑑別診断といら覩点に立つて Békésy オージ
オグラムを見る時，感音性難㯖のあるものに出现する次 の二つの特異な現象を指摘することができる，それは，

1. 振幅の異常縮小

2. 固定周波数閾值が時間の経過と共に上等する現象 である。この2 現象は共汇正常耳，伝音性難聴耳儿は 殆えど認められず，感音性難聴淿特有な現象である。こ れらがいかなる異常聴賞機構と結びついて扣るのか, 又 感音性難聴の細別診断上いかなる意味を有するのか等の 問題については既にかなり詳細な検討がなされている が，決定的判断を下せる程の材料が得難く，なお意見の 一致を見ない部分も残つている。それは動物実験や剖検 による確証を得ることの困難なこの種の心理学的研究手 段のるつ共通した制約によるものであるう、ここでは特 Кこの 2 項目中の振幅とその異常縮小火関する若干の問 題を取上げて検討して見たい，

\section{2. 振幅の構成}

Békésy 9) は自己のオージオメータを発表した論文中 で, このオージオグラムの示す鋸歯状振幅を音の強さの

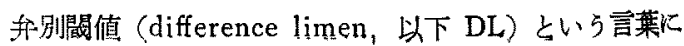


䘏きかえて記载している。 Békésy 自身この DL とい

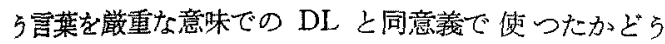

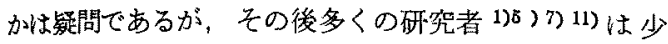
くとも振幅と DL を密接な関係のあるものと見做して きている.

これに対して Hirsh, Palva \& Goodman ${ }^{6)}$ は振幅 活 DL を測定しているのではなく，絶刘䦪値の周明の

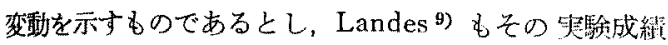
から同し意見を発表している。

振幅が DL と密接な閔係があるかどらか别として， 振幅が音のきこえはじめのレベルときこえなくなるレべ ルとの間の幅（これを閵值幅と㭔んでおく）を示そらと していることは間違いない，ただ Békésy オージオグ ラム上の振幅はこの閔值偪がそのまま示されているので はなく，その他の要团もすべて $\mathrm{dB}$ 值に換算されて維 込李れていることに注意せればならぬ，そしてそれは坂 本 ${ }^{16)}$ の指摘したような被検在の注意力，惯小，精神譏

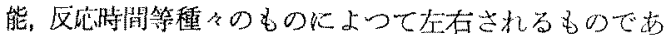
万う. Békésy ${ }^{2}$ 自身6すでに閶值音が full loudness に達するをでに0.5〜1.0秒，さらにスイッチを打すま で隹 0.2 秒を要することを指摘している。一つの振幅値 のなかにはこのような時閶的要素が 2 度含まれることに なるから，上記 Békésy の示した時間数を2倍して dB 值に換算すると，その合計はオージオメータのレベル推 移速度が $2 \mathrm{~dB} / \mathrm{sec}$ であれば 2.8〜4.8dB ということに なる。

このような（広い意味での）反応侍閭を知るためには

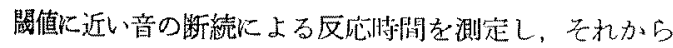

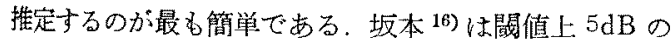
音の断続と，それによつて被檢者がスイッ千を操作する までの時間の $\mathrm{dB}$ 換算值（好みだし）直接 Békésy オーシォグラム上で測定し，この值はレベル推移嗃度 $2 \mathrm{~dB} / \mathrm{sec}$ で2〜 $4 \mathrm{~dB}$ であり，これを除いた真の閾值幅

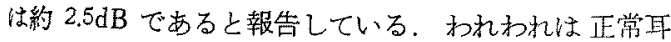
における Békésy 振幅の構成について梌討する日的で 次の1，I，西 の観察を試みた。

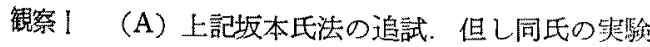
方法では音の㓷続を行ら検者の側の反応時間が測定值 湦入する可能性があると思加れたので，反応封閒を2現 象オシロスコープに撮影された刺激南及びスイッ子操作 の雨波形より測定した（B）閤值上 $5 \mathrm{~dB}$ の学の手胹 による任意盽綕に対する反応時間の測定.

正常4耳に上る成續は第1 表に示すごとく，両方法其
第 1 表 $1000 \mathrm{cps}, 5 \mathrm{~dB} \mathrm{SL}$ 㽦の断緢に対す る区応時間一観察 I

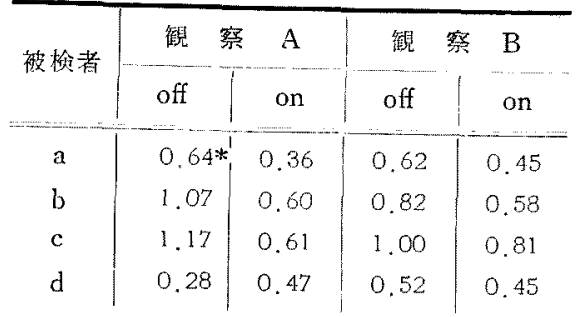

*数值は15〜25国の平均湘定倠，谁经移

ほぼ同一成繢で，on，off 反応㭙間を合計 $L ， \mathrm{~dB}$ 做に 換算すると，レベル推移速度 $2 \mathrm{~dB} / \mathrm{sec}$ の場弇 $1.5 \sim 3.6$ $\mathrm{dB} と な つ た$ (新井峻).

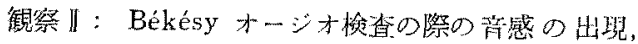
消失は省の增強，減弱によるものでありて，音の断続に

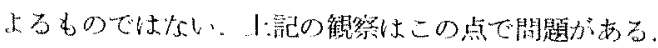

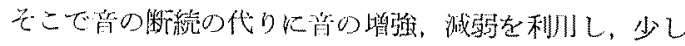
です奏際の状態に近づこら上試みた。即ら被検耳がある 強さの音基準に，これを $5 \mathrm{~dB}$ 減搦，復元を繰返した 際にそれに伴つて音朢の消失，出現を綝返すような強さ の笓を求め, $5 \mathrm{~dB}$ の変化に対する音感の消失，出現に よつてスイッチを操作させ，その反応時間を前記 4 耳に ついて測定した，第2表がその成績で，この值を同じよ うに on, off 合計して dB 值にすると, レベル推移速 度 $2 \mathrm{~dB} / \mathrm{sec}$ の場合で 2.7〜 4.7 dB となり，観察 の音 の断街の場合上りやや大さい值を示す上らになつた（新 茾湾).

第 2 表 $1000 \mathrm{cps}$ 测值背の $5 \mathrm{~dB}$ 㤎化火 対与万反応時間一微察

\begin{tabular}{c|c|c}
\hline 被龽者 & 減 & 增 \\
\hline a & 1.02 & 1.07 \\
$\mathrm{~b}$ & 0.96 & 0.66 \\
$\mathrm{c}$ & 122 & 1.13 \\
$\mathrm{~d}$ & 0.49 & 0.84
\end{tabular}

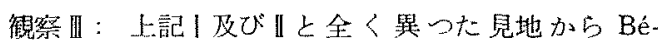
késy 痘幅の棈成を梌討して見た。Békésyオージオグ

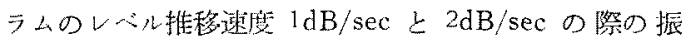
幅を同一人で比較すると，常に後者の力゙が大きい。これ は振腷の中心時閜的要素が含まれており，この部分が $2 \mathrm{~dB} / \mathrm{sec}$ の場命に2倍の振㬏として換算されるためで 
あると解せられる，そこで Békésy 振幅を時間と無関 係の真の䦪值幅 (T) とそ礼以外のすへての時間的要素

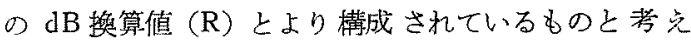
る. そしてこの場合の $\mathrm{R}$ は推移速度 $1 \mathrm{~dB} / \mathrm{sec}$ の場合 に(R/2) になるものとする。

推移速度 $1 \mathrm{~dB} / \mathrm{sec}$ 及び $2 \mathrm{~dB} / \mathrm{sec}$ の際の振幅を $\mathrm{A}_{1}$, A とすると

$$
\begin{array}{ll} 
& \mathrm{A}_{1}=\mathrm{T}+\mathrm{R} / 2 \\
\text { 往つて } & \mathrm{A}_{2}=\mathrm{T}+\mathrm{R} \\
& \mathrm{T}=2 \mathrm{~A}_{1}-\mathrm{A}_{2} \\
& \mathrm{R}=2\left(\mathrm{~A}_{2}-\mathrm{A}_{1}\right)
\end{array}
$$

と, 閔值幅及び反応時閒 ( $\mathrm{dB}$ 換算値) が計算される.

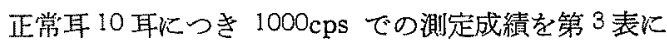
示すが，この上らにして計算すると闌值幅は $0.1 〜 1.7$ $\mathrm{dB}$ (平均 $0.97 \mathrm{~dB}$ ) とかなり小さく，これ以外の時間的 要因はレヘル推移速度 $2 \mathrm{~dB} / \mathrm{sec}$ の場合には $3.0 \sim 6.6 \mathrm{~dB}$ (平均 $4.56 \mathrm{~dB}$ ) 飞達し, 上記I II 0 成績上りさらに

\begin{tabular}{|c|c|c|c|c|}
\hline \multirow{2}{*}{ 被赖者 } & \multicolumn{2}{|c|}{ 振 幅 (dB) } & \multirow{2}{*}{$\begin{array}{c}\text { 閵 值 疅 } \\
(\mathrm{dB})\end{array}$} & \multirow{2}{*}{$\begin{array}{c}\text { 反応時閧 } \\
\text { (dB) }\end{array}$} \\
\hline & $1 \mathrm{~dB} / \mathrm{sec}$ & $2 \mathrm{~dB} / \mathrm{sec}$ & & \\
\hline 1 & 4.1 & 6.9 & 1.3 & 5.6 \\
\hline 2 & 3.5 & 5.5 & 1.5 & 4.0 \\
\hline 3 & 3.0 & 5.5 & 0.5 & 5.0 \\
\hline 4 & 3.3 & 5.9 & 0.7 & 5.2 \\
\hline 5 & 3.4 & 6.7 & 0.1 & 6.6 \\
\hline 6 & 3.7 & 5.7 & 1.7 & 4.0 \\
\hline 7 & 3.0 & 5.6 & 0.4 & 5.2 \\
\hline 8 & 2.7 & 4.2 & 1.2 & 3.0 \\
\hline 9 & 2.9 & 4.7 & 1.1 & 3.6 \\
\hline 10 & 2.9 & 4.6 & 1.2 & 3.4 \\
\hline 平均 & 3.25 & 5,53 & 0.97 & 4.56 \\
\hline
\end{tabular}
大きい值が得られた。

第 3 表 レベル推移速度による振幅差から算出 された閾偩幅と反応時間 $(1000 \mathrm{cps})$ 一 钼察 $\mathbb{I}$

勿椧この成績は Békésy 振幅を一定の仮定の下に構 成した上で得られたもので，站密火云えばやはり一種の モデル実験にすぎないささらに本错察は $2 \mathrm{~dB}$ step の オージオメータを使用していながら step に上る影響を

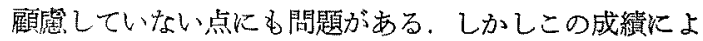

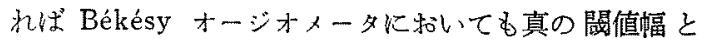

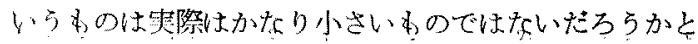

いう推測も生れてくるので，今後さらに条件をととの克 て充分な検討を加えて見る必要があるら（新井埪，坂部 長正).

\section{3. 正常振幅}

振幅の異常縮小を論ずるためには，その前提としてい かなるものを正常とするかの範囲を決定奴礼ならら。. 従来 Békésy オージオグラムの正常振幅に関する記載 として, Lundborg ${ }^{11)}$ 性 50 の正常耳より 6 12dB (多 くは 6〜9dB) の値を出し, Liere \& Reger ${ }^{10)}$ は正常 耳振幅を 4〜10dB としている. Palva ${ }^{18)}$ は 16 人の正 常耳を使用して各周波数ごとに測定し，かなり大きい個 体差のあることを示したが， $5 \mathrm{~dB}$ 未满の振幅を示寸侧 は1 例に過ざなかつたことから，Palva 仙 $5 \mathrm{~dB}$ をる て正常振幅の限界とした. 田口 ${ }^{19)} 5 \mathrm{~dB}$ 末满を異常緶 小としたが，小関 ${ }^{12)} は 16 \mathrm{~dB}$ 以上を增大，5〜15dB 正常，3〜 $4 \mathrm{~dB}$ を移行， $2 \mathrm{~dB}$ 以下を縮小と 4 型飞分類 した.

われわれは 20 30 歳主での正常耳 50 耳によつて固定 周波数の振幅を測定した（リオン1014 型自記オージオ メータ, 減衰器 $2 \mathrm{~dB}$ step, レベル推移速度 $2 \mathrm{~dB} / \mathrm{sec}$ ). その結果は第 4 表に示すごとく，大略 3〜10dB の範围 にあり，平均值も前記 Palva の成續に比べてかない小 さい，この差は扣旮らく装置，特にレベル推移速度，減 衰器の step の $\mathrm{dB}$ 值, 被検者の馿れの程度等によつ 生じたるのであろう（涳田桂）。

第 4 表 正常耳平均振幅

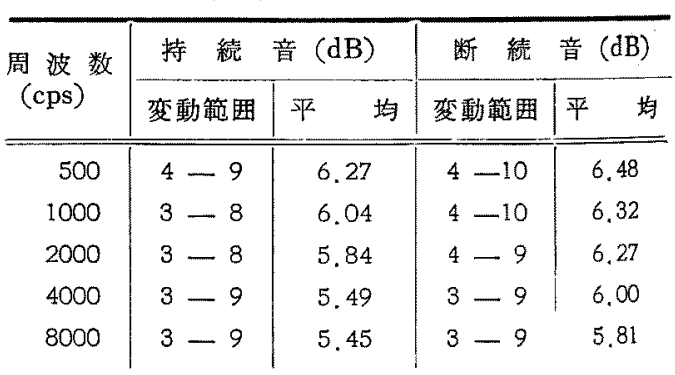

\section{4. 持続音振幅と断続音振幅}

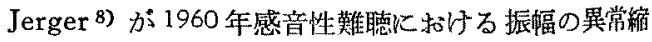
小が持続音に限つて認められ，断続音では認められない ことを指摘して以来，両者の関係が注目されるようにな つた. 前記 Palva は每秒 1,2, 4,8,12 回, on-off 此 $50 \%$ の断続音で正常耳における振幅を㵋定した，その 結果すべての周波数において断続音振幅は持續音振幅よ 
クやや大きい值を示し，その差は 0.1〜1.5dB であつ た. 立木, 坂本等 ${ }^{21)}$ は良く訓練された正常 5 耳を使用 し，断続音 (4/sec, on-off $50 \%$ ) 振幅と持続音振幅 と を比較し，2dB step のオージオメータでは 1000 cps で 約 $1 \mathrm{~dB}, 4000 \mathrm{cps}$ で約 $2 \mathrm{~dB}$ 断続振音幅が大きいといら 結果を示した.

われわれる断続音振幅と持続振音幅 とを 比較して見 た、既㳊第 4 表に示寸ように，平均值に打いてはやはり 寸ぺての周波数に揖いて断続音振幅が持続音振幅より大 きいがそとの差は 0.2〜0.5dB の程度に止つた。

次にわれわれは持続音, 断続音雨種の振幅の関係を考 慮した振幅の正常限界を決定するなめ，第 5 表に示した

第 1 図振幅の正常範囲を示す琵却棈円図形
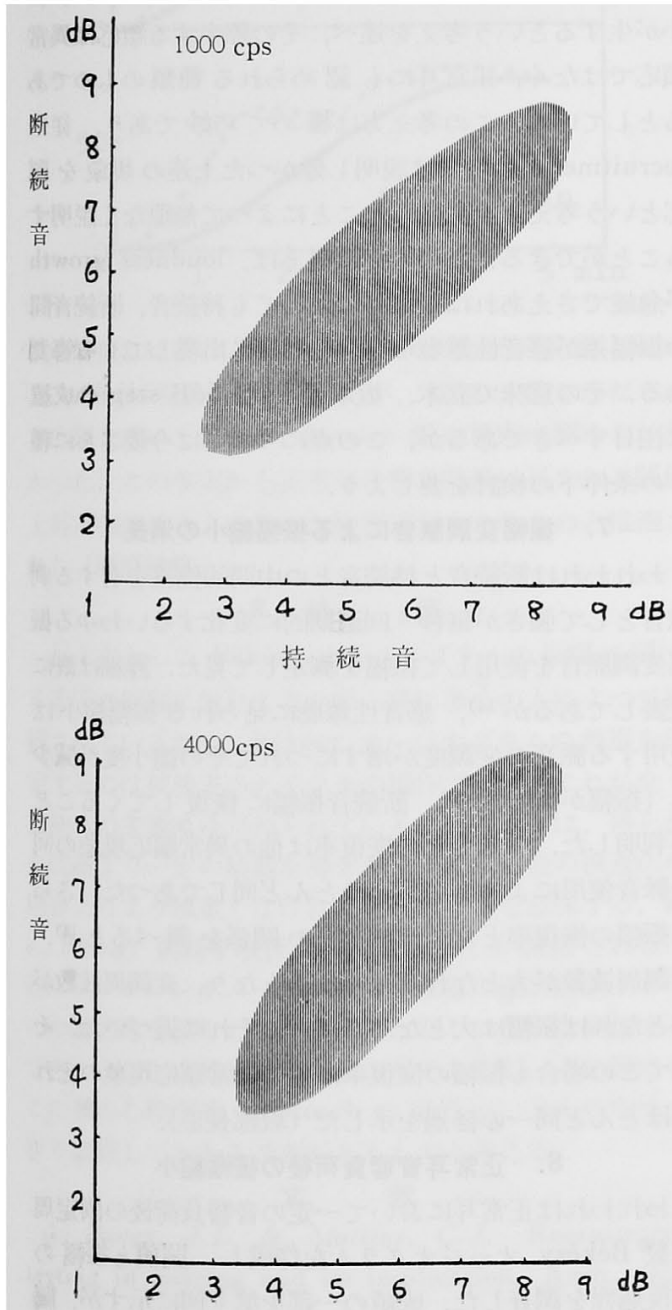

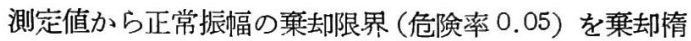
円法によつて求めた、第1 図はそのなかの $1000 \mathrm{cps}$ 及 び 4000cps のものであるが，他の周波数の 図形もほぼ 似た形であつた，この菓却楕円以外にあるものは，たと 光持続音の振幅が正常值の範盲内でも正常とは見なし難 いことを示している（䆶田桂）。

\section{5. 感音性難聴における異常振幅}

感音性難聴における振幅の異常縮小は recruitment の表現として Békésy 以来指摘されている所であるが， 田口 ${ }^{19)}$ は内取性難聴 202 耳中 151 耳（約 $75 \%$ ）飞 $5 \mathrm{~dB}$ 未満の振幅縮小を認めたのに刘し, 後迷路性難聴と思わ れる症例 92 耳中 26 耳 (約 28\%) 飞振幅縮小を認め, 本現象は前者に多いことを示した。 小関 12) む内耳性難 聴 163 耳中振幅 $2 \mathrm{~dB}$ 以下 76 耳 (約 $47 \%$ ), 3〜 4dB 49 耳 $(30 \%)$ を見出し，前記田口の成續とほぼ一致した值 を示した。

われわれは前項の萧却榇円図形を使用し，この上に感 音性難聴（主として内耳性難㯖の振幅を点で描き，衰却 能円以外にはみ出するのの割合を数光て見ると，1000 cps で約 $61 \% ， 4000 \mathrm{cps}$ で約 74\%のものが正常範用を はみ出していることがわからた（第 2 図）．勿論この場 合は正常範囲外のものが総て包含されているのである

第 2 图 感音性難聴耳の振幅，楕円は正常範围 （縦軸断続音，横軸持続音振幅）

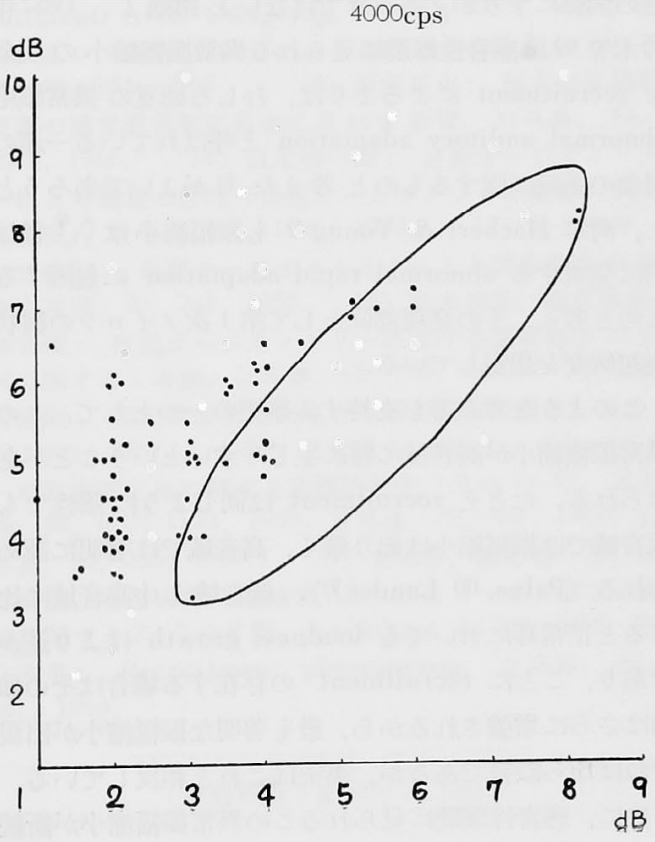


が，やはり持続者振幅の縮小を特徽とするものが異常省 幅の大多数を占めていることはこの図から明㻮に認奶る ことができる(等田桂).

\section{6. 振幅縮小と recruitment}

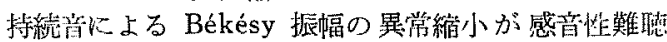

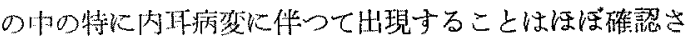

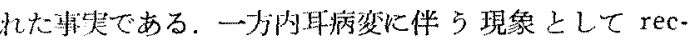
ruitment が知られている (Dix \& Hallpike 3)). 従つ て両者が其に主として内耳性難㯖に出現する現象であ り，彭䉼的には著明な振幅縮小があればこれを内耳病变 の一つの指標と見做してよいといら点では翼論はない。 しかし振腷縮小と recruitment との関係については， 今日意見は一致して和らず，いくつかの考方方が発表さ れているが，多くの者は両者の間の関係を肯定してい る. 即ち，振幅縮小も recruitment も共飞主として内 耳性難聴に認められる現象であり，少くとも recruitment のある将例でないと振幅䋱小山認められないこ と，振幅之閾值上刺激省の DL，值との間には有意の相 関のあること, recruitment があれば閶值附近の loudness は急峻な增大を示す筈で，その結果として振幅縮 小が予想ざれるこ等がその主なる理由としてあげられ ている。

これに対し1960年 Jerger ${ }^{8)}$ は Békésy オージオが ラムと聴器病変所在との関係を，前者と recruitment との関係代すりかえるべきではないと指摘 し，1962年

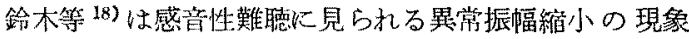
を recruitmentによるよりは，むしろ聴覚の異常䐣応 abnormal auditory adaptation と呼ばれている一連の 現象の系列属するものと考克た方がよいであるらと、 し，同年 Harbert \& Young ${ }^{4)}$ b掁幅縮小は 0.1 秒以 内炕発現する abnormal rapid adaptation 飞起因する ものと考党，その発現部位として第1 次ノイロンの樹状 实起病变を想定している。

この上らな考克方を支持する毫実の一つ上して，この 異常振幅縮小が高音域に特に生じやすいといらことがあ げられる。たとえ recruitmentは同しように陽性でも 低音域では振偪縮小は起り難く，高音域では著明代認め られる(Palva, 13) Landes 9))。低音域性 中高音域に比 こると正常耳に机いても loudness growthは上り速か であり、ことに recruitment の存在する場合はその㑑 向はさらK增強されるから，最も著明な振幅縮小が出現 せねねばなら筈であるが，鿾奉はこれと相反している。

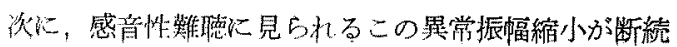

振使用によつては同様には認められないという事実があ る. recruitment が断続音で減少するとは考えられな いから，この異常振幅縮小が recruitment $儿$ 起因寸る よりはむしろ順応に類する現象であるうと考光る方が妥 当であるとするのである

このことを第 2 図について検討して見ると，今持続辛 振幅 $3 \mathrm{~dB}$ 以下のものの断続音振幅の平均䏡 $4.7 \mathrm{~dB}$ で, $3 \mathrm{~dB}$ を越するのの断続音振幅平均 (6.5dB) k比へると 差があり，全休们に見て持続音振幅の小なるもの性続 皃振幅も小である傾向がある。しかし持続音比見られる ような著明な縮小傾向は存在しないから，上述の主張る 理由あるものと見做してよいるのと思われる。

最近立木 ${ }^{229}$ はrecruitment 飞起因する急速な loudness growth によつて順応が出現し，その結果振幅濰 小が生ずるといら考党を述べ，その際生ずる順応は異常 順応ではなく，正常耳とも認められる種類のるのであ るとしている。 この考光方は極めて巧妙であり，従来 recruitment のみでは帨明し難からた上述の現象を順 応という考え方を加味したことによつて無理なく説明す ることができる。この考えに従光ば， loudness growth が急峪でさえあれぱ正常耳に执いても持絸音，断繶音間 の振幅差が感音性難聴の場合と同樣に出現してくる等で ある，その意味で立木，坂本等 ${ }^{21)}$ の $5 \mathrm{~dB}$ step の成漌 は注目すべきであるが，この点については今後さら種 々の条件下の检討を要しょう。

\section{7. 振幅变調脈音による振幅樎小の消長}

われわれは断続音と持続音との中間的性格を有する刺 激音として强さが每秒 4 回週期的に変化するいわかわる振 幅変調脈音を使用して振幅を測定して見た，詳練は既儿 発表してあるが 14)，感音性難聴汇見られる振幅縮小红 使用する眽音の变調度が增すにつれてその縮小度が減少 し（振幅が大となり），断続音振幅恢復してくること が判明した，そしてその恢復率は他の異常順怹現象の同 一眽音使用による恢復率と汪とえど同どであつた，さら に振幅の恢復率と変調周波数との関係を調べると ${ }^{15)}$ ， 変調周波数が大となれば振幅は小となり，変調周波数が 小となれば振幅は大となり断続音のそれに近づいた。 そ してこの場合る振幅の恢復率は他の異常順応現象のそれ とほとんど同一の経過を示した（坂部長正）.

\section{8. 正常耳音響負荷後の振幅維小}

われわれは正常耳に执いて一定の音響負荷後の固定周 波数 Békésy オージオグラムを作成し，闒値と振幅の 恢復過程を調查した，成績の一部を第 3 四に示すが，閔 
第 3 図 純音 $(4000 \mathrm{cps}$ ) 負街後の閏值（点線）

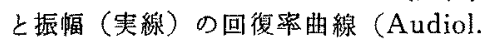
$7,246,1964$ 上り)

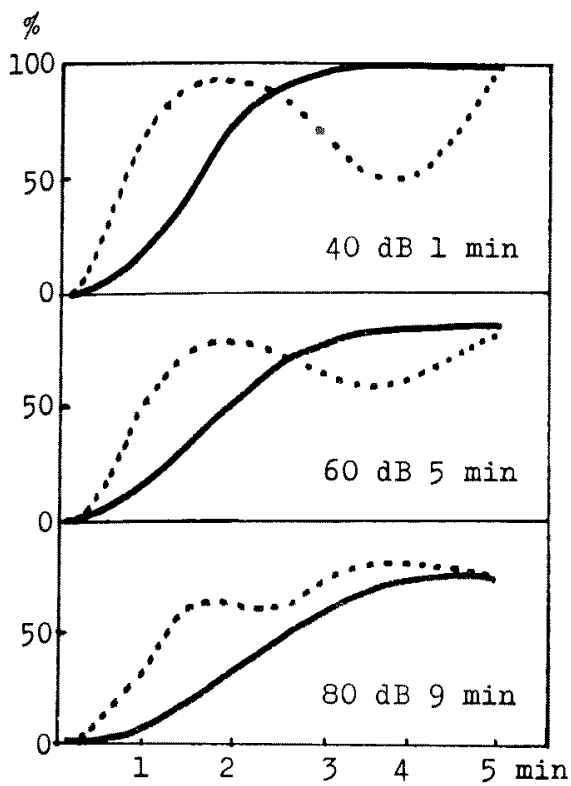

值の恢復には既に Hirsh \& Ward などが発表してい るbounce 現象が諗められたが，振幅の方はなだらか な曲線を画いて质復し， bounce 様の傾间は㤎められな

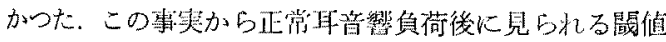

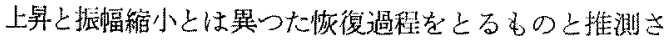
れた（滕原敏修）。

\section{9. 結語}

以上主として Békésy オージオグラムの报幅に間す る若十の閴題に蚛れてきたが，既火多くの人によつて指 摘されている如く，Békésy オージオグラムの波形を淤 定するのは被検者のスイッチの操作であり，これが全く 被険者の主観にゆだ稀られているといらことは，得られ

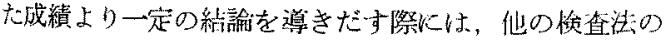
場合よりより慎重でなければならぬことを害味する。特 に Békésy 握幅を取扱う際にこのこしが痛聶される。

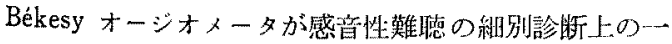
つの有加手段として今後何等か新しい領域を開拓する であるらことは充少予想される听であるが，支の㻮心も

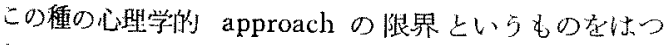

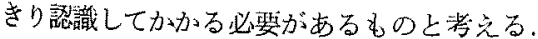

\section{文献}

1) Bangs, J.L. \& Mullins, C.J. Recruitment testing in hearing and its implication, Arch. Oto- laryng. 58, 582, 1953.

2) Békésy, G.: A new audiometer, Acta oto-lạryng. 35, 411, 1947. 3) Dix, M.R., Hallpike, C.S. \& Hood, J.D. Observation upon the loudness recruitment phenomenon with special reference to the differential diagnosis of the internal ear and the eighth nerve, J. Lary. ng. 52, 672, 1948, 4) Harbert, F. \& Young, M.: Clinical application of hearing tests, Arch. Otolaryng. 76, 55, 1962. 5) Hedgecock, L.: The measurement of auditory recruitment, Arch. Otolaryng. 62, 515, 1955. 6) Hirsh, I.J., Palva, T. \& Goodman, A.. Difference limen and recruitment, Arch. Otolaryng. 60, 525, 1954, 7) Hormia, A.L.: Difference limen of intensity in hearing impairment due to craniocerebral injury, Laryngoscope $68,808,1958 . \quad$ 8) Jerger, J.: Bekesy audiometry in analysis of auditory disorders, J. Speech \& Hear. Res. 3, 275, 1960.9 9) Landes, B.A.. Recruitment measured by automatic audiometry, Arch. Otolaryng. 68, 685, 1958. 10) Liere, D.M. \& Reger, S.N.: Further studies of threshold shilts as measured with the Békésy-type audiometer, Ann. Otol. Rhin. Laryng. 63, 772, 1954.

11) Lundborg,T.: Diagnostic problems concerning acoustic tumors. A study of 300 verified cases and the Békésy audiogram in the differential diagnosis, Acta oto-laryng. Suppl. 99，1952. 12) 小関進：自

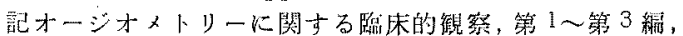
日舟乘, 62, 1105; 1364; 1756, 1959. 13) Palva, T.: Self-recording threshold audiometry and recruitment, Arch. Otolaryng. 65, 591, 1957 . 14) 吸

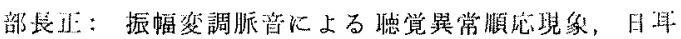

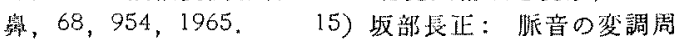

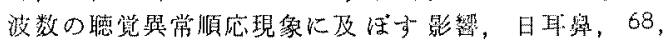
1073，1965. 16) 坂本伸一郎: 自旡才ージィ一夕

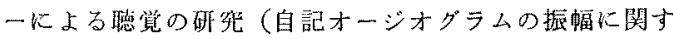

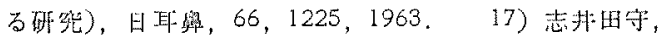

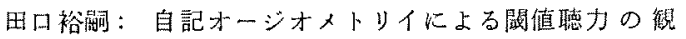

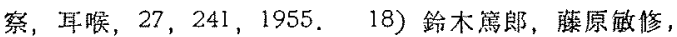
新井峻：自記オージオメトリ一に括ける振輻維小の成 凡に関する1考察，HF鼻，65，751，1962。19) 四

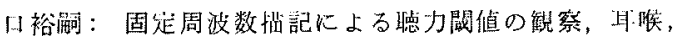

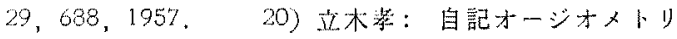

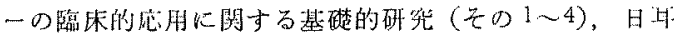

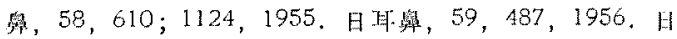

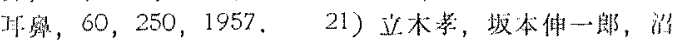

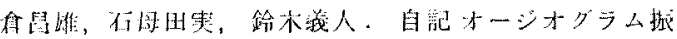

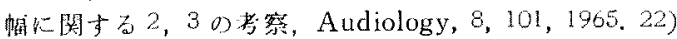

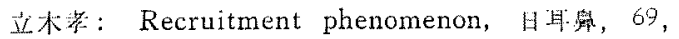
$461,1966$.

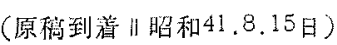

